\title{
Lean and Productivity in The Financing of Health Services
}

\author{
Menekşe Kiliçarslan ${ }^{1 *}$, Rana Özyurt Kaptanoğlu ${ }^{2}$ \\ ${ }^{1}$ İstanbul Aydın Üniversitesi, Sağlık Yönetimi, Istanbul- Türkiye (ORCID: 0000-0002-0580-8645) \\ ${ }^{2}$ Medipol Üniversitesi, İktisadi İdari Bilimler Fakültesi, (DSÜ) İşletme Yönetimi Bölümü, İstanbul, Türkiye (ORCID: 0000-0002-0341-4722)
}

(First received 28 December 2018 and in final form 5 March 2019)

(DOI: $10.31590 /$ ejosat.504719)

ATIF/REFERENCE: Kilicarslan, M. \& Kaptanoglu, R. O. (2019). Lean and Productivity in the Financing of Health Services. European Journal of Science and Technology, (15), 297-301.

\begin{abstract}
Financing health services plays an important role in ensuring control and the utilization of expenditures. Because of this, the appropriate selection of the financing should be done with utmost care. Hospitals debts have doubled in the last four years. The most important reason of this is that patients can easily reach all of the hospitals, necessary tests and surgeries that the performance system has brought. When the problems of hospitals are analysed from a general perspective, because of the SSI and performance system, institutions have entered in a severe bottleneck and have been severely restricted (Erkol and Ağırbaş, 2011: 88). The same process continues in the official institutions. In the private institutions, the situation has started to be somewhat different, and the differences arising from case-by-case payments have begun to be received from the patient underhandedly.
\end{abstract}

Keywords: Budget, SSI (Social Security Institution), Health, Finance

\section{Sağlık Hizmetlerinin Finansmanında Yalın ve Verimlilik}

Öz

Sağlık hizmetlerinin finanse edilmesi, kontrolün sağlanmasında ve harcamaların kullanılmasında önemli bir rol oynamaktadır. Bu nedenle uygun finansman seçimi özenle yapılmalıdır. Son dört yılda hastaneler borçları iki katına çıkarmıştır. Bunun en önemli nedeni, hastaların performans sisteminin getirdiği tüm hastanelere, gerekli testlere ve ameliyatlara kolayca ulaşabilmeleridir. Hastanelerin sorunları genel bir bakış açısıyla analiz edildiğinde, SGK ve performans sistemi nedeniyle kurumlar ciddi bir darboğaza girmiş ve ciddi şekilde kısıtlanmıştır (Erkol ve Ağırbaş, 2011: 88). Resmi kurumlarda da aynı süreç devam etmektedir. Özel kurumlarda durum biraz farklılaşmaya başlamış ve duruma göre ödemelerden kaynaklanan farklılıklar hastadan alınmaya başlanmuştır.

Anahtar Kelimeler: Bütçe, SGK (Sosyal Güvenlik Kurumu), Sağlık, Finans

\footnotetext{
Corresponding Author: İstanbul Aydın Üniversitesi, Sağlık Yönetimi, Istanbul- Türkiye, ORCID: 0000-0002-0341-4722, meneksevaro169@gmail.com
} 


\section{Introduction}

Pricing policy is a part of administration decisions in all sectors and price is based upon demand and supply at the end of the day. Increase in the costs of health services is a result of growing health expenses. Hence, pricing in the health services gains more importance day by day. Estimation of the costs of health service is also important in terms of prevention the unexpected results that affect the quality of health services (Raulinajtys, 2014: 341). The most significant aim in the health sector is to provide timely and quality services users need. However, not knowing the exact time when the need of service arises, increases the financial burden besides making the calculation of possible costs, which occur during the time of need, difficult (Tatar 2016:105). Health financing prevents service users from financial burden as a main goal (WHO, 2002). Health financing is defined as funding of costs, arising from health services or transfer between funds. Transfer is made between service providers, service users and a third payer part. While service providers make transfer to service users, in exchange for this provided service, third payer parts make transfer to the service providers as payment in exchange for the services they provide (Uğurluoğlu, 2008: 135). This cycle between service providers, service users and third party payer is shown in the Figure 1.

Figure 1: The Triangle of Health Service

\section{Providing Service}

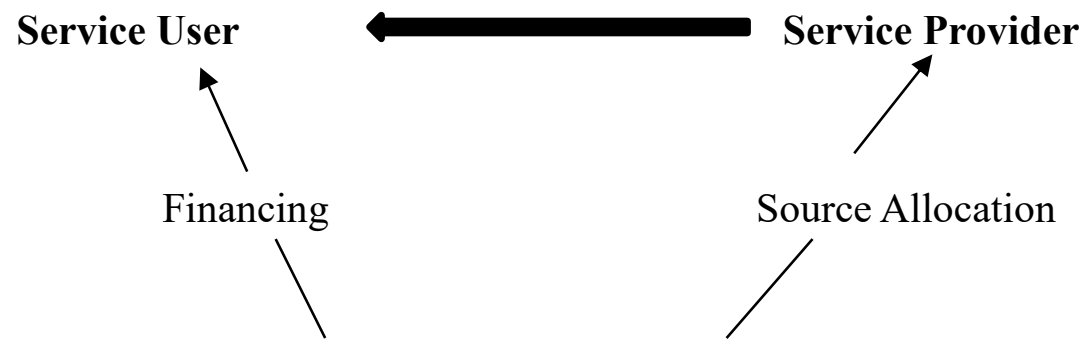

\section{Third Party Payer}

Source: Mossailos and Dixon, 2002, Cited by Tatar,

Financing of health services has three main functions as revenue collection, fund gathering and remitting. Revenue collection includes of which health personnel makes the payment and which amount s/he makes and its scope. Financing methods like taxes, private health insurance, personal medical saving accounts, contribution of users generates the revenue collection. Financial risk is shared when financial burden, generated by suddenly occurrence of service need, is gathered on the all members. Hence, individuals that need less health service support individuals that need much more health service. Fund gathering is also named as insurance. In addition, payments of the service providers are made with various methods like payment per service, payment per day, payment per case, payment per capita, global budget (İstanbulluoğlu, Güleç and Oğur, 2010:90).

\section{Financing Methods in the Health Services}

There are significant inequality in the categorization of sources, which is spent for global health. The economic development of a country is closely related to the state of health of its population. In the countries with low income, annual expense per capita is under 100 dollars. This creates the lack of accessibility to the sources and hinders providing quality service. On the other hand, in the countries, where expense per capita is 5.000 dollars, this is reflected on the policies in a different way (Ensor and Ronoh, 2005: 49).

When the definition of health services is analysed, it is as practices for the protection of human health, treatment and rehabilitation when necessary. Organizations that provide health services should be handled in a different way from the other organizations, for they provide urgent and irrecusable services. Hence, the nature and characteristics of services provided by organizations that provide health services, is required financing structures, unique to them (Arrk and İleri, 2016: 80). Health financing has an important role in the effective operation of health services and provides financial stimulus and source for the effective operation of health system (Akortsu and Abor, 2011: 128). The aim of health financing is to create a continuous source for the users of health services to access health services (İstanbulluoğlu and et. al. 2010:90).

For the purpose of effectively carrying out the financing of health services in the hearth systems, it is possible to mention various financing models. Financing models, such as financing with taxes, Social health insurance, and private health insurance, out-of-pocket expenses, medical saving accounts, are used in the health systems (Kılıçaslan, M. 2016:113).

Financing with taxes (Beveridge Model) In the event that private sector is used for the financing health systems, personal benefit comes into prominence, income-generating services are focused, preventive services can be neglected and people without ability-to- 
pay cannot benefit from the provided services. This decreases the service quality and causes hitches in the system. That's why, how health services is financed is a significant issue (Çelikay and Gümüş, 2010:192).

In this model, also called as Beveridge Model, government assumes the guarantor role and meets all financing of provided health services. In the Beveridge model, health services are not distinguished from other types of services, they are dealt with like a road or lightning service (Daştan and Çetinkaya, 2015:106). The model, generally adopted in the Scandinavian countries such as Finland, Sweden, Norway, has some features like the control of health services financing through budget, free access of health services for service users, adopting the capitation method for the reimbursement to the service providers (Tatar, 2011: 111).

Bismarck Model It is a model, based on sickness funds, created according to the individuals' working types, or investing some part of their income on a third party payer. The model was developed by Bismarck in Germany so it is identified with the German health system. Bismarck model embraces not only the working class but also the non-active population (Arık and İleri, (2016:81).

Out-of-pocket Expenses Unnecessary service demand, one of the problems, which affects the productivity of health services, has prompted decision makers to search for new policies. Payment system with the contribution of users is one these policies. The method, one of which eliminates the risk of health services financing and meets the need of health services financing, is not only an advance payment mechanism but also a financing source that is paid directly to the service provider at the moment of getting services (www.sagem.gov.tr). Due to the ambiguity of the time when the demand for health services occur and unforeseeable of how much burden would be placed on the users, it is not suitable to use only this payment model even though it prevents the unnecessary service demand (Daştan and Çetinkaya, 2015: 108).

For the control of health expenses, growing all over the world, providing the continuity of health services financing has become an obligation. Besides, reimbursements, paid to the service providers in exchange for the health services, should be paid by determining the best method within the health systems. Selection of the method in an optimal way is highly important for the financial success of the system. Methods of reimbursements in the health services can be listed as per case payment, per service payment, per capita payment, per day payment, groups related to treatment and global budgets (Arık and İleri, (2016:83).

\section{Reimbursement Methods in the Health Services}

According to the per case reimbursement method, a predetermined amount of payment is made to the health service providers for every patient (case), who gets health services because of a disease or a certain reason. Here, payments are made to health providers under certain circumstances and considering the case. There are two methods to determine the payment. While a small amount is paid without considering the disease in the first method, payments are made with considering the diagnosis in the second method. System is developed for the prevention of the disadvantages of per service reimbursement method.

While the idea that per case reimbursement is made by minimizing the use of source is considered as one of the strong sides of the system, the blind side of the system is that health providers prefer patients with low-cost treatment or easier treatable patients (Akyürek, 2012: 192, Arık and İleri, 2016:84).

Per Service Payment Method, A predetermined fixed amount of payment is made to health providers in the per service reimbursement method, which is one of the methods of retroactive payments. There is a fixed amount of payment for each service item and services provided by health providers are charged to them at the rate of these prices (Kelat, 2015).

While the strong side of the system can be shown as the tendency of health providers to provide much more health services to patients, unpredictability of services to be provided for the service users make the costs of payments uncertain. This can be shown as one of the weak sides of the system.

Per Day Payment; Organizations, providing health services are paid per period. All expenses (treatment, prosthesis, drugs, accommodation) within this period are paid per day. Health services include different specialities and the same price is paid regardless of the differences even though costs are not the same in every unit or for every patient (Merih.net).

This reimbursement model prompts organization, providing health services, to extend the duration of hospital stay. This also causes the decrease in the service quality provided to the patient.

Per Capita Payment System: It includes the registered per capita payment in exchange for providing health services to all people, registered in a specific geographical region or a registered population defined to itself at a given time (http://www.sdplatform.com). The advantageous side of this payment is that it can decrease the costs. Not only health providers 
prevent the possible unnecessary costs but also it prompts sources to be used in an efficient way (Arrk and İleri, 2016:85). As in the other methods, this method also has negative sides like long waiting line, preference of patient with lower risk by health providers.

Global Budget: Global budget, one of the prospective payment methods, is the expense limit, which is paid for the health services provided by health providers in a fiscal year (Arı and İleri 2016:87). In this payment method, payments are made not in groups but on one payment item. Organization, providing health services, has the freedom to use this budget whichever field it needs (Çelik, 2011:229). The main aim of the global budget is to limit the total cost, which is spent to the health services and control the expenses. Global budget is generally based on an agreement. There should be a consensual amount, which includes all costs of the healthcare organizations. The more income sources in the global budget are, the more possible accessibility to the predetermined policies is (Akyürek, 2012:139). The study is based on the comparison of before and after of the transition of a health care organization to the global budget.

\section{The Use of Global Budget in the Health System in Turkey}

Both service supply and service demand are provided in a combined way in the structure of Turkish health system. While service supply is provided by different public and private healthcare organizations, service demand is made over the difference between people who has the insurance coverage and people who do not have (Yurdadoğ, 2007:592). Health expenses, formed in this complicated and fragmental structure, are met by the government and governmental institutions like the SSI (Social Security Institution) or private sector like organization payments and out-of-pocket expenses. The combined structure of the system makes the effectiveness of it difficult (Top, 2011).

The current reimbursement method in our country is that the Social Security Institution meets the handling fee, which is paid to the service providers by considering the procedures and prices in the attachment of health practices notice, which is determined according to the nature of the provided health services. These procedure charges are invoiced as "payment for diagnose based procedures" or per service payment to the SSI (Arı and İleri, 2016: 87).

\section{Results and Discussion}

Before the transition to global budget, beneficiaries used to apply to the primary care healthcare organization through health certificate with medical examination form or dispatch form. While patients with health card for uninsured people used apply with them, users without health insurance used to pay out of their pocket. After the examination in the primary care healthcare organizations, request slip, showing the examination and workups was kept by copying the papers of analysis and examination in the organization, the original papers were sent to the provincial directorate of health on a monthly basis.

The provincial directorate of health used to make out invoices by dividing these papers, sent by the primary care healthcare organizations in the province, on the basis of per capita and reimbursement organizations. Invoices made out by the provincial directorate of health on behalf of reimbursement organization, were sent to the organization by adding a copy in the attachment of invoices by post (SB: 2014:58-59). By copying other hospitals, additional improvement can be made. However, it is necessary to use lean concepts for new striking improvements by including workers in their own developments process and determination of lean and reframing the processes (Kılıçaslan, M. 2016:117).

Payments of these invoices and attachments were made if deemed suitable in this method, which bureaucracy and costs were high, however; organizations could not have their shares from these payments most of the time. When it was surmised that this method was inefficient during the budget discussions in 2006, the global budget practice came into effect in order to make no concessions regarding the service quality and increase the patient satisfaction (Arı and İleri 2015:87). In the study, the comparison of the efficiency of healthcare organizations before and after the transition to the global budget will be made. The waste of paper will be decreased more with the transition to digital hospitals in the reimbursements of the health sector. In addition, reimbursements will be made faster by the SSI.

\section{References}


Akyürek. C. E. (2012)." Global Budget as a Reimbursement Method in Health and Turkey” Journal of Social Security. v:2 p: 124154.

Ağırbaş, İ. (2011). Hastanelerde Maliyet Analizi ve Faaliyet Tabanlı Maliyetleme. Ankara Üniversitesi Tıp Fakültesi Mecmuasl, 64(02), 087-095.

Akortsu, M., Abor, P. (2011). "Financing public healthcare institutions in Ghana" Journal of Health Organization and Management Vol. 25 say1: 2, 2011 pp. 128-141

Ensor, Tim and Ronoh, Jeptenkeny (2005) " Effective financing of maternal health services: A review of the literature" Health Policy. $\mathrm{V}(75): \mathrm{i}(1) \mathrm{p}: 49-58$.

Uğurluoğlu and Özgen, (2008). 'Health Services Financing and Equity' Hacettepe Journal of Health Administration. V:11 I:2 p:133160.

İstanbulluoğlu, Güleç and Oğur. (2010). "Financing Methods of Health Services" Dirim Medicine Paper. V:85 I:2 p: 86-99.

Raulinajtys, Monica. (2014) 'Cost accounting models used for price-setting of health services: An international review" Health Policy. p: 341-353.

Çelikay and Gümüş, (2010). "Health Services and Financing in Turkey" Eskişehir Osmangazi University Journal of Social Security. Volume: 11 issue: 1 p: 177-126.

Arık and İleri, (2016). 'Refund Systems in Healthcare and Global Budget” Gümüşhane University Journal of Health Sciences. V:5 i:4 p:78-92

Kelat, (2015) "Refund Systems, Financial Sustainability, Leaks in the Medical Bills and Auidt of Court of Account within the Income Aspect" retrieved from https://www.tkhk.gov.tr/Dosyalar/f7d1ca73a5784c578742b97078504574.pptx on 16 ${ }^{\text {th }}$ September 2017

Kaptanoğlu,R.(2017) "An Application on Organisational Commitment and Emotional Intelligence" Balkan and Near Eastern Journal of Social Sciences, (IBANES) 2017, 3(3). http://www.ibaness.org/bnejss/2017 03 03/010 Kaptanoglu.pdf

Kilıçaslan, M. (2016). A Study on an Integrated Model Proposal for Leaning of Healthcare Services, Beykent University, Unpublished Doctoral Dissertation, İstanbul.

Tatar. M. (2011). 'Financing Health Care Services: Development of Social Health Insurance in Turkey’ The Journal of Social Security. $\mathrm{v}: 1$ i:1

T.R. The Ministry of Health. "2014 Activity Report of The Ministry of Health”, p:58-59. https://sgb.saglik.gov.tr (16.09.2017)

Top, M. (2011). "Turkish Health System and Policies" retrieved from http://www.academia.edu/2923094/T\%C3\%BCrk Sa\%C4\%9Fl\%C4\%B1k Sistemi ve Politikalar\%C4\%B1 (16.09.2017). 